\title{
Coral tissue microstructure and necrosis: relation to catastrophic coral mortality in Panamá
}

\author{
Peter W. Glynn ${ }^{1}$, Esther C. Peters ${ }^{2}$ \& Leonard Muscatine ${ }^{3}$ \\ ${ }^{1}$ Smithsonian Tropical Research Institute, P. O. Box 2072, Balboa, Panamá* \\ ${ }^{2}$ Graduate School of Oceanography, University of Rhode Island, Narragansett, Rhode Island 02882, USA \\ ${ }^{3}$ Department of Biology, University of California, Los Angeles, California 90024, USA
}

\begin{abstract}
During 1983, patchy but extensive mortality of several stony coral species occurred off the Pacific coast of Panamá, associated with loss of their symbiotic zooxanthellae. This disturbance was coincident with the prolonged 1983 El Niño waming event. Normally colored colonies receiving bleached colony portions in iso-, allo- and xenografts remained in a healthy state during a 7 mo period. Neither these transplantation experiments, nor histopathological examinations, revealed the presence of an infectious agent which might be responsible for the widespread bleaching, although suspected bacteria were found in electron microscopy preparations of 2 species of bleached corals. The condition of affected coral tissues ranged from slight to severe atrophy and necrosis, but normal-appearing zooxanthellae remained in all but the most necrotic specimens, although reduced in numbers. These observations suggest that environmental (particularly high thermal) stress may have been responsible for the coral deaths.
\end{abstract}

\section{INTRODUCTION}

Reef-building corals suffered catastrophic mortality off the Pacific coast of Panamá from early to late 1983 (Glynn 1983, 1984). Most coral species lost symbiotic zooxanthellae ('bleached') during this period and some species' populations were severely reduced in size or even extirpated locally. Certain coral species were only slightly discolored, showing a partial loss of zooxanthellae, and later recovered. Those species most seriously affected typically showed total colony bleaching and signs of morbidity about 5 to $6 \mathrm{wk}$ following bleaching. This event lasted about 9 mo (Feb-Nov), with bouts of bleaching and mortality occurring over this period. Patches of coral ranging from several to hundreds of $\mathrm{m}^{2}$ bleached and died, to be followed 2 to 3 mo later by equal-sized patches on other parts of reefs. This epizootic-like disturbance suggested that an infectious agent might be involved. We report here the timing of events, the results of transplantation experiments (grafting bleached corals

\footnotetext{
- Present address: Division of Biology and Living Resources, Rosenstiel School of Marine and Atmospheric Science, University of Miami, 4600 Rickenbacker Causeway, Miami, Florida 33149, USA
}

to fully colored colonies) and the condition of affected coral tissues as examined by electron microscopy and histopathological methods.

\section{METHODS}

This study was conducted chiefly on the Uva Island reef $\left(7^{\circ} 48^{\prime} 48^{\prime \prime} \mathrm{N}^{\prime} 81^{\circ} 45^{\prime} 35^{\prime \prime} \mathrm{W}\right)$, one of numerous coral reefs affected in the Gulf of Chiriqui, Pacific coast of Panamá, in 1983. The reef was visited 4 times during the approximately 9 mo disturbance, on 18 to 21 March 1983, when coral bleaching and death were first noted, 26 to 28 April, 23 to 24 June, and on 29 to 30 October, when only a few of the remaining live corals showed signs of bleaching and morbidity. Observations were also made approximately monthly in the Taboga Islands $\left(8^{\circ} 47^{\prime} 40^{\prime \prime} \mathrm{N}_{;} 79^{\circ} 32^{\prime} 30^{\prime \prime} \mathrm{W}\right)$, Gulf of Panamá.

In the transplantation experiments, 4 to $5 \mathrm{~cm}$ long pieces of coral were broken from bleached or normal colonies and grafted to normal or bleached colonies, respectively. Isografts were effected through intracolony transplantations, allografts through intercolony transplantations in a given species, and xenografts through interspecific transplantations. The grafts were fitted snugly into host colonies (between 
Table 1. Coral species collected for microscopic examinations

\begin{tabular}{|c|c|c|c|}
\hline Species & Condition & $\begin{array}{l}\text { Microscopic } \\
\text { technique }\end{array}$ & $\begin{array}{l}\text { Collection } \\
\text { information }\end{array}$ \\
\hline Millepora intricata Milne-Edwards & Bleached & Light & $\begin{array}{l}\text { Uva Island reef } \\
23 \text { June } 1983 \\
3-12 \text { m depth }\end{array}$ \\
\hline Gardineroseris planulata (Dana) & $\begin{array}{l}\text { Normal } \\
\text { Partially bleached } \\
\text { Bleached }\end{array}$ & $\begin{array}{l}\text { Light } \\
\text { Light } \\
\text { SEM }\end{array}$ & \\
\hline Pavona clavus Dana & $\begin{array}{l}\text { Normal } \\
\text { Bleached }\end{array}$ & $\begin{array}{l}\text { Light } \\
\text { Light, SEM }\end{array}$ & \\
\hline Pavona gigantea Verrill & $\begin{array}{l}\text { Normal } \\
\text { Bleached }\end{array}$ & $\begin{array}{l}\text { Light } \\
\text { Light }\end{array}$ & \\
\hline Pavona varians Verrill & $\begin{array}{l}\text { Normal } \\
\text { Partially bleached } \\
\text { Bleached }\end{array}$ & $\begin{array}{l}\text { Light } \\
\text { Light } \\
\text { TEM, SEM }\end{array}$ & \\
\hline Porites lobata Dana & Normal & Light & \\
\hline Porites panamensis Verrill & Bleached & Light, SEM & \\
\hline Psammocora stellata Verrill & $\begin{array}{l}\text { Normal } \\
\text { Partially bleached }\end{array}$ & $\begin{array}{l}\text { Light } \\
\text { Light }\end{array}$ & \\
\hline Pocillopora elegans Dana & Bleached & SEM & \\
\hline \multirow[t]{2}{*}{ Pocillopora damicornis (Linnaeus) } & $\begin{array}{l}\text { Partially bleached } \\
\text { Bleached }\end{array}$ & $\begin{array}{l}\text { Light } \\
\text { Light }\end{array}$ & \\
\hline & $\begin{array}{l}\text { Normal } \\
\text { Bleached }\end{array}$ & $\begin{array}{l}\text { Light, SEM } \\
\text { Light }\end{array}$ & $\begin{array}{l}\text { Urabá reef, } \\
\text { Taboga Islands } \\
14 \text { June } 1983 \\
4 \text { m depth }\end{array}$ \\
\hline
\end{tabular}

branches or in fissures) or occasionally wired to insure tissue contact. The condition of grafts and host colonies was observed in situ 1, 3 \& 7 mo later.

Samples of normal and bleached colonies of several species were collected and fixed for light and electron microscopy (Table 1). Samples for histopathological examination were fixed in Helly's solution (Barszcz \& Yevich 1975) for $20 \mathrm{~h}$, rinsed in freshwater for $24 \mathrm{~h}$, then wrapped in cotton cloth soaked in $70 \%$ ethanol and shipped to the University of Rhode Island. Coral skeletons were removed with Decal solution (S/P). Tissues were trimmed, washed in running water for 24 $h$, and processed by standard techniques for embedding in Paraplast (Yevich \& Barszcz 1980, Peters et al. 1983). Sections $6 \mu \mathrm{m}$ thick were cut and stained with Harris' hematoxylin and eosin, Heidenhain's aniline blue method for connective tissue (to reveal mesogloea and condition of zooxanthellae), and modified Movat's Pentachrome technique (to reveal mucus secretory cells). Additional slides of Pocillopora damicornis were stained with Bielschowsky's silver method. Other samples of Pavona gigantea and Pavona clavus were collected in July 1984, processed and stained with PAS-alcian blue ( $\mathrm{pH}$ 1.0)-hematoxylin and Taylor's modification of Brown \& Brenn's method for Gram- positive and Gram-negative bacteria (Luna 1968). Tissues were examined with a Zeiss Photomicroscope III.

Samples for transmission electron microscopy were fixed in $2.5 \%$ cold glutaraldehyde/formaldehyde $(5 \%)$. After fixation, material was rinsed in $0.2 \mathrm{M}$ cacodylate buffer, $\mathrm{pH} 7.4$, and decalcified in a solution of $10 \%$ EDTA in $0.03 \mathrm{M} \mathrm{NaOH}$ over a $10 \mathrm{~d}$ period. The tissues were dehydrated in a graded series of ethanol solutions $(30,50,70,90$ and 3 changes of absolute ethanol), $30 \mathrm{~min}$ at each step. Specimens were transferred to absolute ethanol:propylene oxide $(1: 1)$ for $1 \mathrm{~h}$, then into propylene oxide:medacast epoxy (1:1), and finally into $100 \%$ medcast epoxy for overnight infiltration. Tissues were embedded in fresh plastic the following day. Thin sections were collected on 200 mesh copper grids which had been coated with parloidion and a carbon film and stained with uranyl acetate and lead citrate. Grids were examined with a Philips 300 electron microscope operating at $60 \mathrm{kV}$.

For scanning electron microscopy, fixed specimens were subdivided into small pieces and transferred directly to graded ethanol series or, for cryofracture, placed in the EDTA decalcifying solution as described above. After decalcification, samples were dehydrated in the ethanol series. From $100 \%$ ethanol, samples 


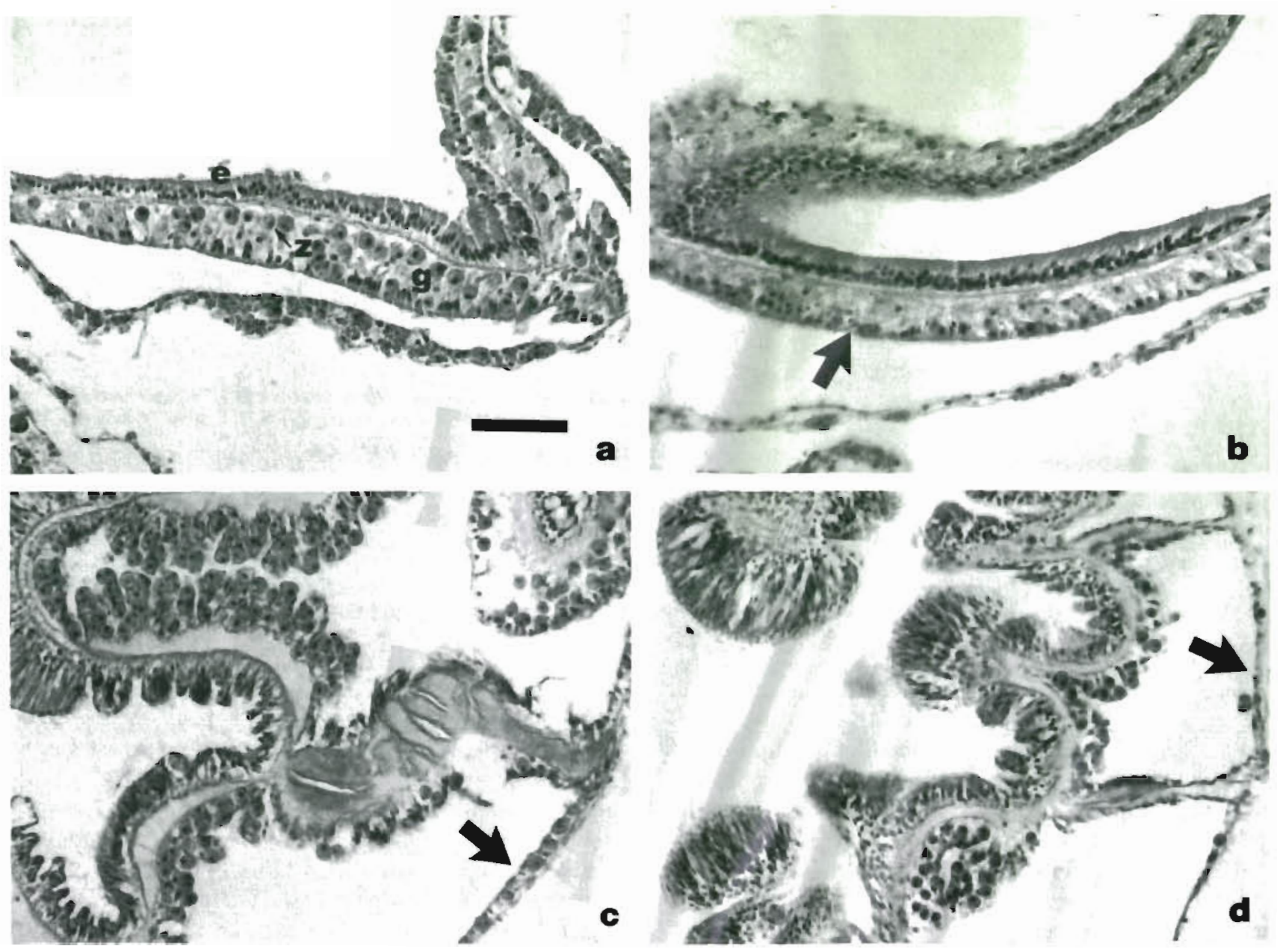

Fig. 1. Light micrographs of normal and 'bleached' coral tissue. (a) Pavona gigantea. Photomicrograph of tissue from 'healthy' colony, Uva Island, Gulf of Chiriquí (23 June 1983). Note distinct cellular architecture and staining characteristics. This species possesses a reduced epidermal cell layer with few mucosecretory cells (e) and a thickened granular gastrodermal cell layer (g) containing zooxanthellae (z). Stained with hematoxylin and eosin. Scale bar $=50 \mu \mathrm{m}$ (same for all figures). (b) $P$. gigantea. Tissue from partially 'bleached' colony, Uva Island, Gulf of Chiriquí (23 June 1983). Note loss of zooxanthellae from gastrodermis (arrow) and atrophy of tissues. Hematoxylin and eosin. (c) Pocillopora damicornis. Photomicrograph of tissue from tentacle region of 'healthy' polyp, Urabá, Gulf of Panamá (14 June 1983). Note distinct cellular architecture. Hematoxylin and eosin. (d) $P$. damicornis. Cross-section of polyp from 'bleached' colony, Uva Island, Gulf of Chiriquí (23 June 1983). This section was taken from slightly higher on the polyp than Fig. 2c. Note loss of zooxanthellae and atrophy of tissues, as well as increase in epidermal nuclei, indicating cellular changes in this tissue. Hematoxylin and eosin

were critical point dried, or for cryofracture, frozen in parafilm tubes in liquid nitrogen, fractured with a razor blade, and then critical point dried in a Polaraon E3000 Critical Point Drier. All specimens were mounted on stubs, sputtercoated with gold in a ISI 5000 sputter coater, and examined with an ISI-DS-130 SEM.

\section{RESULTS}

Coral bleaching occurred in patches, and involved the majority of colonies and species in circumscribed areas. Visual estimates indicated that 50 to $80 \%$ of all live corals were affected on the Uva reef in mid March.
This increased to 80 to $95 \%$ of the original live cover by the end of April. Bleaching, morbidity and death continued into June, and a few corals were still affected in late October. Some coral patches that had escaped bleaching in March and April contained numerous colonies in a bleached and morbid condition in June. By the end of October, 85 to $95 \%$ of all corals on the Uva reef were dead. The species most affected were hydrocorals (Millepora, 3 species), and scleractinian corals (Pocillopora, 3 species and Porites panamensis).

Although partially-bleached, bleached, and recently dead corals were observed in abundance from March through October, tissue sloughing was only rarely 
Table 2. Condition of coral transplants on a Panamanian coral reef (Uva Island, Gulf of Chiriqui) affected by catastrophic coral mortality in 1983

\begin{tabular}{|c|c|c|c|c|}
\hline Species & $19 \mathrm{Mar}^{1}$ & $27 \mathrm{Apr}$ & $24 \mathrm{Jun}$ & $29 \mathrm{Oct}$ \\
\hline \multirow[t]{8}{*}{ Pocillopora damicornis } & Isografts, $\mathrm{n}=5$ & All grafts dead & All hosts alive & All hosts dead \\
\hline & Isografts, $\mathrm{n}=5$ & All grafts alive & All grafts dead & - \\
\hline & Allografts, $\mathrm{n}=12$ & All grafts dead & All hosts dead & - \\
\hline & - & Allografts, $n=2$ & All grafts dead & All hosts dead \\
\hline & $\begin{array}{l}\text { Xenografts (Gar. } p l n .^{2} \text { ) } \\
\mathrm{n}=16\end{array}$ & All grafts dead & All hosts alive & All hosts alive \\
\hline & $\begin{array}{l}\text { Xenografts (Gar. pln.) } \\
\mathrm{n}=5\end{array}$ & $\begin{array}{l}2 \text { grafts alive } \\
\text { all hosts dead }\end{array}$ & 1 graft alive & All grafts dead \\
\hline & - & $\begin{array}{l}\text { Xenografts (Gar. pln.) } \\
\mathrm{n}=5\end{array}$ & All grafts dead & All hosts alive \\
\hline & $\begin{array}{l}\left.\text { Xenografts (Poc, elg. }{ }^{2}\right) \\
n=3\end{array}$ & All grafts dead & All hosts dead & - \\
\hline Pocillopora elegans & Allografts, $\mathbf{n}=5$ & All grafts dead & All hosts alive & All hosts alive \\
\hline $\begin{array}{l}\text { Gardineroseris } \\
\text { planulata }\end{array}$ & Allografts, $\mathbf{n}=10$ & $\begin{array}{l}\text { All grafts and } \\
\text { hosts alive }\end{array}$ & $\begin{array}{l}\text { All grafts and } \\
\text { hosts alive }\end{array}$ & $\begin{array}{l}\text { All grafts and } \\
\text { hosts alive }\end{array}$ \\
\hline
\end{tabular}

seen. The first sign of stress in Pocillopora damicornis was the bleaching of branch-tips over most of the colony. The bleached polyps were expanded normally, but usually the whole colony died in 4 to 6 wh after the initial bleaching. It is probable that numerous colonies shed their tissues nearly simultaneously and died within a period of a few days.

Lack of an obvious relation between coral death and severe environmental conditions, such as pollution and/or eutrophication, suggested that an infectious agent might be involved in the sporadic outbreaks. This motivated the following transplantation experiments. Isograft and allograft transplants in Pocillopora spp. did not affect the mortality pattern of these corals (Table 2). This was also the case with xenograft transplants between $P$. damicornis and Gardineroseris planulata. Except for minor tissue damage along zones of contact, an expected result in allogeneic and xenogeneic grafting (Hildemann et al. 1977), $G$. planulata revealed a relatively high overall survival $(83.9 \%)$ over the 7 mo period. Among the 3 coral species tested, the normally pigmented (and presumably healthy) colonies receiving bleached grafts remained in a healthy state for the duration of the study.

Generally, those colonies collected for their normal coloration appeared healthy under the light microscope with good cellular architecture and staining characteristics, although the actual cellular structure and composition varied with the species (Fig. $1 \mathrm{a} \& \mathrm{c}$ ). An exception to this was a sample of Pocillopora dami- cornis from Urabá, Gulf of Panamá (Fig. 1c). Although its condition was better than the other bleached samples of this species, early stages of necrosis were evident, with loss of distinct architecture and staining of tissue components, and a slight basophilic tinge to the mesoglea in some areas. Few $P$. damicornis colonies with normal coloration remained at this site by July 1983 (S. Gilchrist pers. comm.).

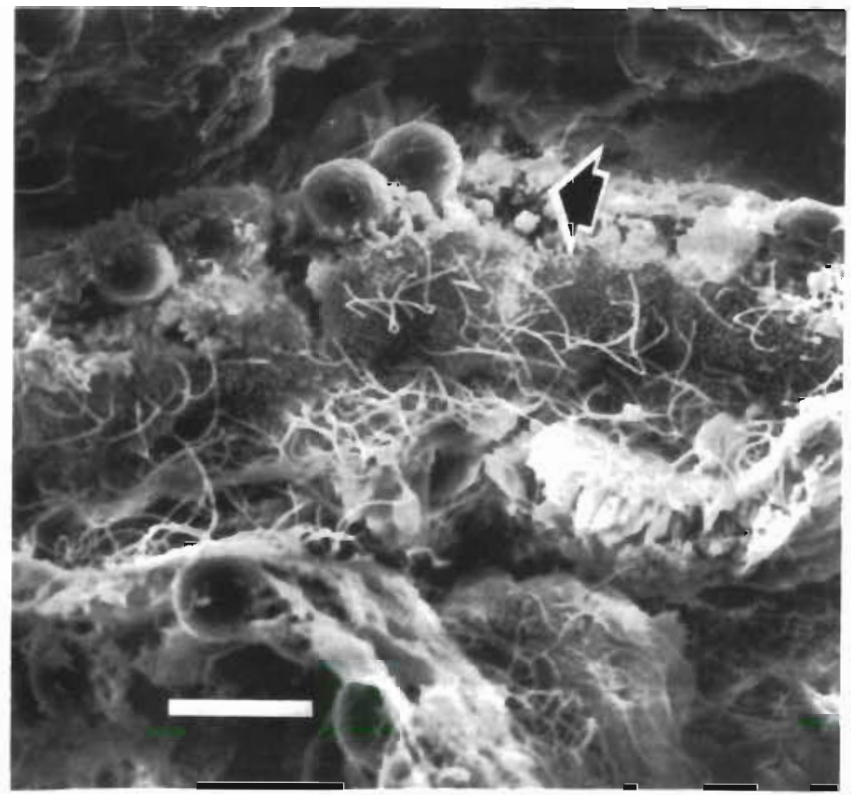

Fig. 2. Pavona varians. Scanning electron micrograph of bleached tissue, showing small spherical granules in gastrodermis. Scale bar $=25 \mu \mathrm{m}$ 


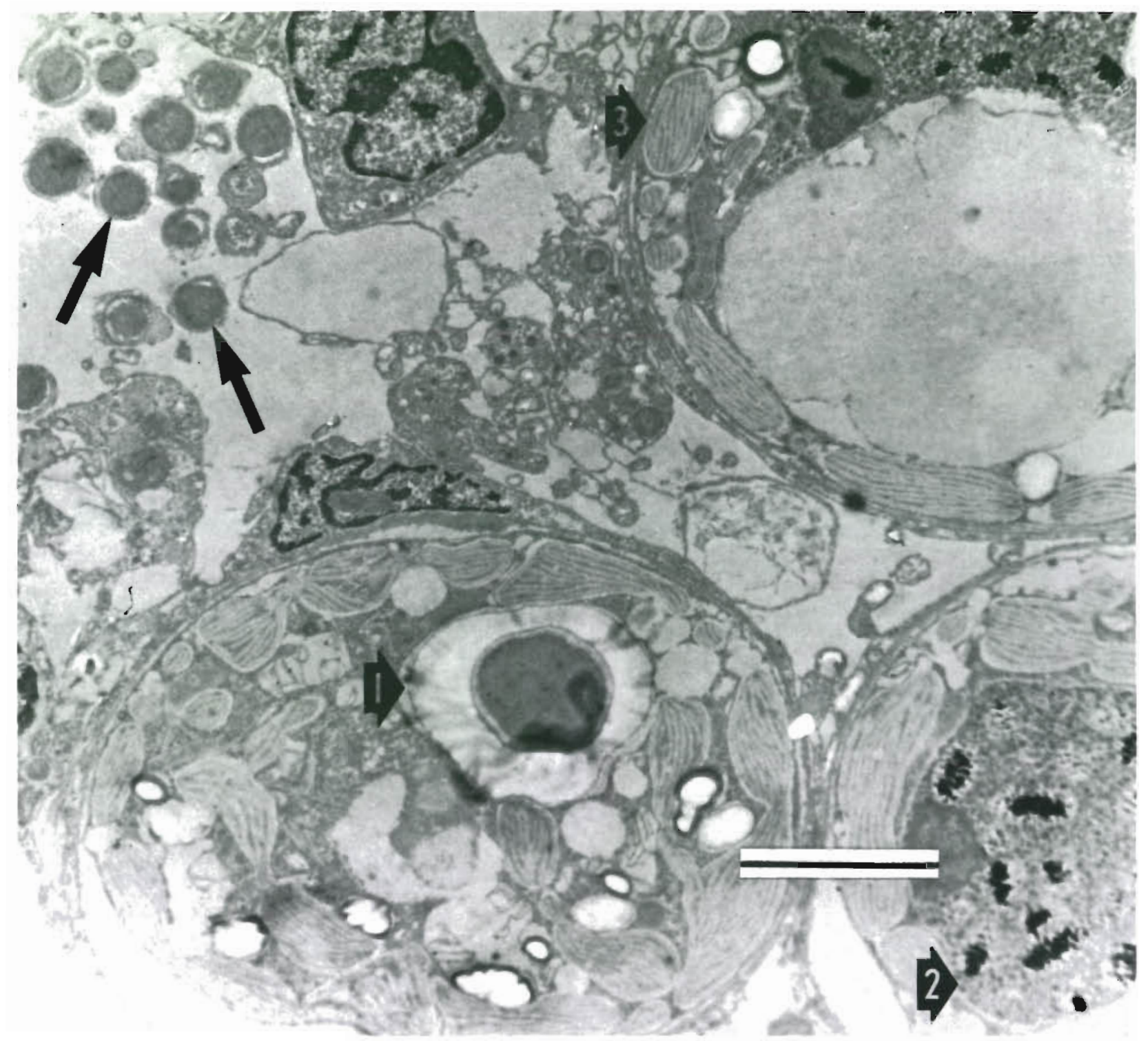

Fig. 3. Pavona varians. Transmission electron micrograph of circular membrane-bound vesicles in gastrodermis (at unnumbered arrows). Large ovoid bodies are zooxanthellae in individual vacuoles $(9460 \times)$. Scale bar $=5 \mu \mathrm{m}$. Numbered arrows: 1 , pyrenoid; 2, nucleus; 3 , chloroplast

All of the partially or completely bleached specimens exhibited varying degrees of tissue atrophy and necrosis (Fig. 1b \& d). The partially-bleached specimen of Gardineroseris planulata showed only slight changes which might be within normal individual variability for this species. Samples of Pavona clavus showed an increase in mucous secretory cells of the epidermis, but $P$. gigantea and $P$. varians had decreased mucous secretory cells compared to the 'normal' samples. Epidermal mucous secretory cells in some areas of all $P$. clavus, $P$. varians, and $G$. planulata contained basophilic material in 'blobs' rather than the usual 'stringy' appearance, similar to that observed in corals collected from the Caribbean coast of Panamá which were also bleaching (Lasker et al. 1983). The peculiar composition of these cells has also been noted in corals from other Caribbean locations (Peters 1984), but not in such abundance. This condition probably represents a stage in mucus production. Mucus secretions in Psammocora stellata had changed to a 'foamy' appearance in the necrotic tissue. Changes in staining characteristics were evident in the epidermis of Pentachrome-stained sections of $P$. stellata, Porites panamensis, and $P$. clavus indicating changes in mucus composition and $\mathrm{pH}$. The epidermis of the bleached samples of Pocillopora damicornis had a 

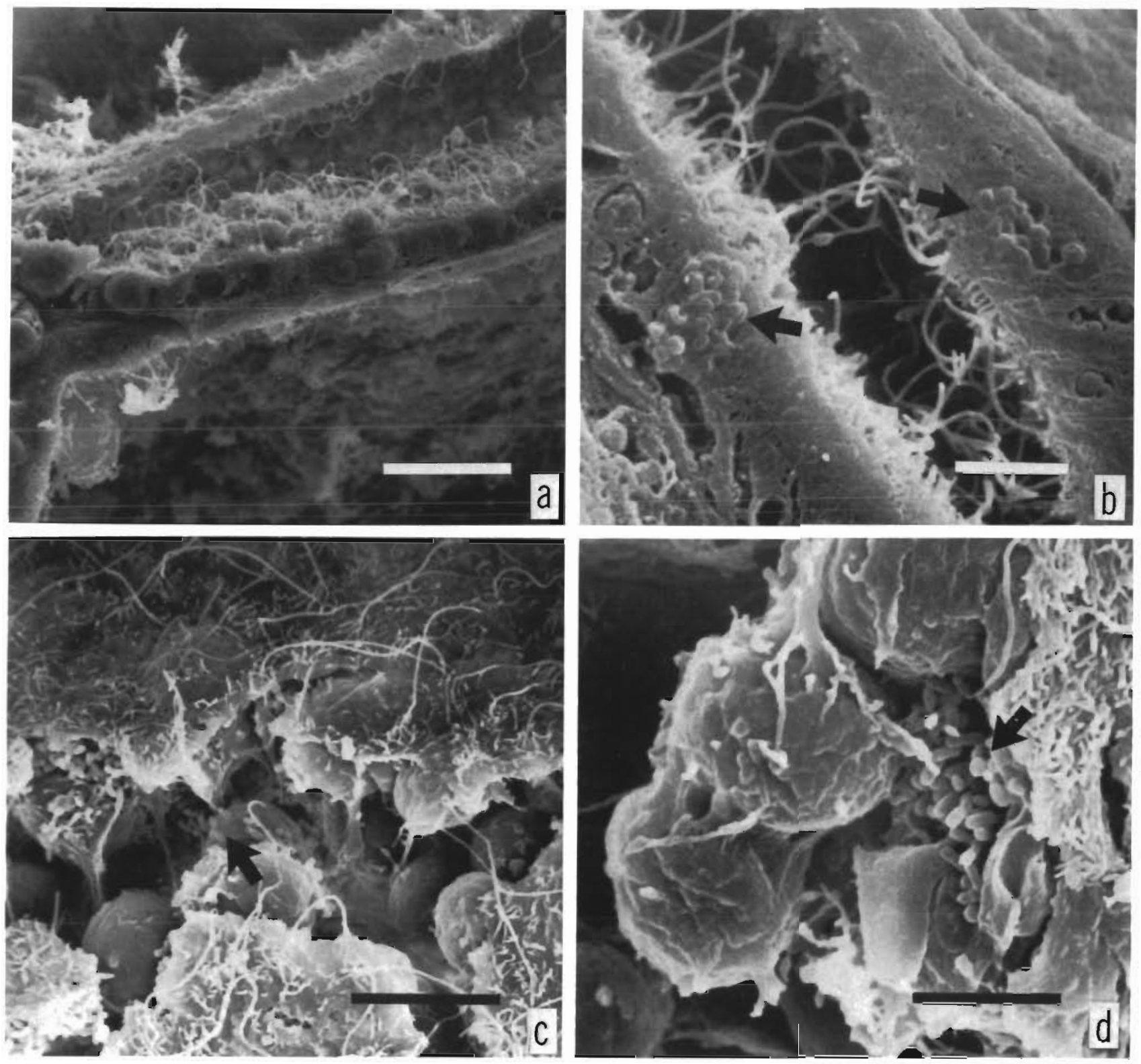

Fig. 4. Scanning electron micrographs of coral tissues prepared by the cryofracture technique. (a) Normal Pocillopora damicornis; fractured surface of mesentery. Note zooxanthellae in abundance in separate vacuoles in gastrodermal cells, and flagellated coelenteric canal. Scale bar $=20 \mu \mathrm{m}$. (b) Bleached Pocillopora elegans. Note absence of algae in gastrodermis and clusters of spherules in cells. Scale bar $=5 \mu \mathrm{m}$. (c) Bleached Pavona varians, showing rod-shaped bacteria-like objects in gastrodernal cells; large spheres are zooxanthellae. Scale bar $=10 \mu \mathrm{m}$. (d) $P$. varians. Higher magnification of fractured tissue with bacterialike objects. Scale bar $=5 \mu \mathrm{m}$

peculiar appearance, resembling a proliferation of fibrocytes, but the silver stain revealed only necrotic cells, with a loss of mucous secretory cells. Necrosis of the tissues in this species was further marked by an increased basophilia of the mesoglea. This was not observed in any other species.

Little tissue remained on the skeleton of the hydrocoral Millepora intricata, and this was necrotic, with degenerating zooxanthellae. In the partially bleached scleractinian corals, zooxanthellae concentrations remained high in most tissue areas, and appeared in normal condition. Bleached colonies showed fewer algae in their gastrodermal cells and the latter revealed increased vacuolation. The condition of the algae ranged from healthy-appearing, to degenerating, to only algal pigment debris remaining. Gonads were found in several of the colonies examined (Gardineroseris planulata and Pavona clavus), but their 
condition was related to the general state of health of the coral tissue. Developing and large mature ova were observed in the normal samples of Pavona gigantea and Psammocora stellata, respectively, but their bleached counterparts lacked any signs of gonad development. No gonads were observed in any of the samples of Pocillopora damicornis or the 2 Porites species.

No microorganisms were found in any of the coral tissues with the light microscope techniques, although suspected bacteria were observed in the gastrodermis of the bleached Pavona varians and Pocillopora elegans colonies (Fig. $2 \& 4$ b). Circular profiles suggestive of coccoid microorganisms were found in $P$. varians by transmission electron microscopy (Fig. 3). These membrane-bound vesicles contained an electron-opaque substance, but did not show the usual bacterial organization. Cryofractured tissues revealed the presence of spherical to rod-shaped bacteria-like objects in the gastrodermal cells, sometimes occupying zooxanthellae vacuoles, in both species.

\section{DISCUSSION}

While the interspersion of patches of affected and visibly normal corals suggested the periodic outbreak of a contagious agent, no infections resulted from the transplantation experiments which involved direct tissue contact between bleached and normally pigmented colonies. This result is in marked contrast to the transmission of 'black band disease' (Rützler et al. 1983) or 'shut-down-reaction' (Antonius 1977) between colonies in direct contact. If a pathogen or microparasite were responsible for the coral bleaching, it seems reasonable that some sign of transmission would have occurred in the coral transplants over the 7 mo observation period.

Bacteria are not uncommonly found on otherwise healthy corals (Sorokin 1973, Ducklow \& Mitchell 1979), but can increase in number and contribute to tissue necrosis when the coral encounters adverse environmental conditions which promote increased mucous secretion (Mitchell \& Chet 1975, Rublee et al. 1980). Although increased mucous secretory cell activity was observed in some of the colonies examined during this study, other specimens showed decreases. Under the light microscope, samples of Pavona varians were necrotic, with much cell debris, particularly in the gastrodermis lining the calicoblastic epithelium. It is possible that bacteria were present in these necrotic cells, as was observed under the scanning electron microscope. The samples taken for electron microscopy came from a more bleached colony. Since these bacteria-like objects were not found in other species, it appears that they could have secondarily colonized the necrotic coral tissue, and were not primarily responsible for the bleaching and atrophy of the tissues. No bacteria were revealed in the majority of the normal and bleached colonies examined by SEM or light microscopy

Two additional lines of evidence suggest that the widespread mortality of corals in the eastern Pacific was due to some factor other than a disease. Widespread bleaching and mortality were first observed in March and April in Panamá and the Galápagos Islands (Glynn 1984), areas separated by about $1,300 \mathrm{~km}$ and with only 2 small intervening island groups. Previous epizootic outbreaks have been confined to relatively small areas at different times (Bak \& Criens 1982, Dungan et al. 1982, Gladfelter 1982, Scheibling \& Stephenson 1984), or have affected larger areas contemporaneously by spreading with currents and subsequently infecting new populations (Smith 1941, Lessios et al. 1984).

The second observation that argues against an infectious agent was the simultaneous bleaching and death of corals in the eastem Pacific Ocean basin (Gulf of Panamá) and the Caribbean Sea (north coast of Panamá). Although these areas are close geographically $(80 \mathrm{~km})$, they are separated by the Isthmus of Panamá. The Panama Canal traverses the isthmus, but contains fresh-water for most of its length (Jones \& Dawson 1973). It seems unlikely to us that a marine disease organism could transit the canal under present conditions, and histopathological examinations of Caribbean coral tissues did not reveal any pathogenic microorganisms (Lasker et al. 1984).

It should also be noted that most coral diseases have relatively low rates of intracolony propagation. 'White band disease' (WBD), possibly caused by a bacterium (Peters et al. 1983), results in necrosis and sloughing of acroporid tissues (from base to branch-tips) at about $6 \mathrm{~mm} \mathrm{~d} \mathrm{~d}^{-1}$ (Gladfelter 1982). 'Black-band disease' (BBD), caused by a cyanophyte, destroys tissue at an average of $3 \mathrm{~mm} \mathrm{~d}^{-1}$ (Garrett \& Ducklow 1975, Rützler et al. 1983). In contrast, bleaching and morbidity in eastern Pacific corals occurred suddenly and affected entire colonies simultaneously. The most actively growing parts in all species, e.g. summits of massive corals or branch tips in ramose species, were most seriously affected. The shaded areas of colonies in some species were minimally affected and recovered relatively quickly. However, in no case were localized points or zones of morbidity observed as in WBD and BBD afflictions.

The 'shut-down reaction' (SDR) seems to share some similarities to the symptoms noted in this study (Antonius 1977, 1982): (a) SDR acts quickly, causing complete colony death in a matter of hours; (b) SDR 
may be triggered by extreme environmental conditions (see below). However, unlike the response in Panamic corals, SDR proceeds without any initial bleaching, and is highly contagious. Also, SDR invariably kills entire colonies. While entire colonies of some species succumbed in Panamá (e.g. all species of Millepora and Pocillopora, and Porites panamensis), certain species showed only partial colony death and subsequent recovery (e.g. Pavona spp., Gardineroseris planulata, and Porites lobata).

Changes in environmental conditions such as temperature, salinity, light, or starvation may cause either sudden bleaching, in which strands of mucus laden with zooxanthellae are expelled through the stomodaeum, or gradual loss of pigment either by reduced numbers of algae or by decreased amounts of zooxanthellae pigment (Yonge \& Nicholls 1931, Goreau 1964, Franzisket 1970, Coles \& Jokiel 1978, Jaap 1979, Rogers 1979). Although affected corals were not examined histologically in any of these reports, the corals frequently recovered their pigment slowly as conditions returned to normal. However, tissues of some species have been observed to atrophy with bleaching, and corals have also suffered mortalities after bleaching. As noted on the Panamá reefs, bleaching of the upper sunlight-exposed portions of corals was also observed in Hawaii by Jokiel \& Coles (1977) during laboratory experiments in which corals were exposed to higher than normal water temperatures. Pocillopora damicornis was the most sensitive species. Although most colonies recovered, the bleached areas died. In Panamá, the timing of bleaching corresponded with the appearance and persistence of sea surface warming, suggesting that abnormally high water temperatures could have played an important role in this event (Glynn 1984). While high herbicide concentrations were also found in affected Panamanian corals (Glynn et al. 1984), widespread coral bleaching occurred in the Galápagos Islands, an area that experienced marked sea warming in 1983, but that is free of pesticide use.

The results of the histopathological examinations in this study indicate that the coral animal was primarily affected and that there were species-specific differences in the appearance of the tissues as related to the visually observed bleaching. Many zooxanthellae remained in the gastrodermal cells, degenerating only when the animal tissue was most necrotic and autolysis of the coral cells may have caused necrosis of the algae. Although the reasons for zooxanthellae loss are little understood (Jaap 1979), they appear to be related to changes in the coral metabolism. Such changes may be indicative of sensitivity by the particular species of coral to the stress. However, they may also be related to metabolic changes caused by decreased nutrient acquisition. For most reef corals, the major share of their nutritional requirements is met by the products of zooxanthellae photosynthesis (Johannes 1974, Porter 1976, Muscatine et al. 1981). Therefore, damage to the zooxanthellae (which might appear normal under the microscope) by adverse environmental conditions, could initiate metabolic disturbances and lead to atrophy of tissues, expulsion or emigration of the zooxanthellae, and necrosis. Zooxanthellae productivity decreases when temperatures exceed $28^{\circ} \mathrm{C}$ (Coles \& Jokiel 1977). Microscopic counts of zooxanthellae per unit surface area for bleaching corals exposed to high temperatures revealed no significant changes in numbers of algal cells, but there were significant decreases in algal photosynthetic pigments per cell (Coles \& Jokiel 1978).

In conclusion, although bleaching of the coral tissue may have been initiated by some environmental stress or syndrome (e.g. the prolonged ocean warming during the severe 1982/83 El Niño event: Halpern 1983, Kerr 1983, Glynn 1984, Lasker et al. 1984), loss of the symbionts or their nutritional products could have contributed to the atrophy, later necrosis and coral deaths in the Gulf of Chiriquí and Gulf of Panamá in 1983. Patchiness and variability in bleaching may be due to species' specific differences in metabolism, nutrient sources and/or the ability to adapt to thermal stress (Coles \& Jokiel 1977, Jokiel \& Coles 1977), or the thermal-sensitivity of different strains of zooxanthellae (Schoenberg \& Trench 1980).

Acknowledgements. We thank S. Gilchrist, J. Morin and A. Velarde for assistance in the field and the collection of specimens. P. Yevich provided facilities and assistance with histopathological examinations of the coral tissues. We also thank B. Muller for assistance with the scanning electron microscopy, M. Eiserling for preparing the electron micrographs, and P. Johnson and J. McN. Sieburth for helpful discussions. The study was supported by the Scholarly Studies Program, Smithsonian Institution, Washington, D. C., USA.

\section{LITERATURE CITED}

Antonius, A. (1977). Coral mortality in reefs: a problem for science and management. Proc. 3rd Intl. Coral Reef Symp., Miami 2: 617-623

Antonius, A. (1982). Coral reef pathology: a review. Proc, 4 th Intl. Coral Reef Symp., Manila 2: 3-6

Bak, R. P. M., Criens, S. R. (1982). Survival after fragmentation of colonies of Madracis mirabilis, Acropora palmata and $A$. cervicomis (Scleractinia) and the subsequent impact of a coral disease. Proc. 4th Intl. Coral Reef Symp., Manila 2: 221-227

Barszcz, C. A., Yevich, P. P. (1975). The use of Helly's fixative for marine invertebrate histopathology. Comp. Path. Bull. 7:4

Coles, S. L., Jokiel, P. L. (1977). Effects of temperature on photosynthesis and respiration in hermatypic corals. Mar Biol. 43: 209-216 
Coles, S. L., Jokiel, P. L. (1978). Synergistic effects of temperature, salinity and light on the hermatypic coral Montipora verrucosa. Mar. Biol. 49: 187-195

Ducklow, H. W., Mitchell, R. (1979). Bacterial populations and adaptations in the mucus layers on living corals. Limnol. Oceanogr. 24: 715-725

Dungan, M. L., Miller, T. E., Thomson, D. A. (1982). Catastrophic decline of a top carnivore in the Gulf of California rocky intertidal zone. Science 216: 989-991

Franzisket, L. (1970). The atrophy of hermatypic reef corals maintained in darkness and their subsequent regeneration in light. Int. Revue ges. Hydrobiol. 55: 1-12

Garrett, P., Ducklow, H. (1975). Coral diseases in Bermuda. Nature, Lond. 253: 349-350

Gladfelter, W. B. (1982). White-band disease in Acropora palmata: implications for the structure and growth of shallow reefs. Bull. mar. Sci. 32 (2): 639-643

Glynn, P. W. (1983). Extensive 'bleaching' and death of reef corals on the Pacific coast of Panamá. Environ. Conserv. 10: $149-154$

Glynn, P. W. (1984). Widespread coral mortality and the 1982/ 1983 El Niño warming event. Environ. Conserv. 11: $133-146$

Glynn, P. W., Howard, L. S., Corcoran, E., Freay, A. D. (1984). The occurrence and toxicity of herbicides in reef building corals. Mar. Pollut. Bull. 15: 370-374

Goreau, T. F. (1964). Mass expulsion of zooxanthellae from Jamaican reef communities after Hurricane Flora. Science 145: $383-386$

Halpern, D. (1983). Editor's note. Tropical Ocean-Atmosphere Newsletter 21:1

Hildemann, W. H., Raison, R. L., Hull, C. J., Akaka, L., Okumoto, J., Cheung, G. (1977). Tissue transplantation immunity in corals. Proc. 3rd Intl. Coral Reef Symp., Miami 1: $537-543$

Jaap, W. C. (1979). Observations on zooxanthellae expulsion at Middle Sambo Reef, Florida Keys. Bull. mar. Sci. 29: $414-422$

Johannes, R. E. (1974). Sources of nutritional energy for reef corals. Proc. 2nd Intl. Coral Reef Symp, Brisbane 1: 133-137

Jokiel, P., Coles, S. L. (1977). Effects of temperature on the mortality and growth of Hawaiian reef corals. Mar. Biol. 43: 201-208

Jones, M. L., Dawson, C. E. (1973). Salinity-temperature profiles in the Panama Canal locks. Mar. Biol. 21: 86-90

Kerr, R. A. (1983). Fading El Niño broadening scientists' view. Science 221: 940-941

Lasker, H. R., Coffroth, M. A., Lessios, H. A., Morin, J., Peters, E. C., Shulman, M. (1983). Extensive bleaching of Caribbean corals in the San Blas Islands, Panamá. Coral Reef Workshop, Am. Soc. Zool., Philadelphia (oral presentation)

Lasker, H. R., Peters, E. C., Coffroth, M. A. (1984). Bleaching of reef coelenterates in the San Blas Islands, Panamá. Coral Reefs 3: 183-190
Lessios, H. A., Robertson, D. R., Cubit, J. D. (1984). Spread of Diadema mass mortality through the Caribbean. Science 226: $335-337$

Luna, L. G. (ed.) (1968). Manual of histologic techniques of the Armed Forces Institute of Pathology, 3rd ed. McGrawHill, New York

Mitchell, R., Chet, I. (1975). Bacterial attack of corals in polluted seawater. Microb. Ecol. 2: 227-233

Muscatine, L., McCloskey, L. R., Marian, R. E. (1981). Estimating the daily contribution of carbon from zooxanthellae to coral animal respiration. Limnol. Oceanogr. 26: 601-611

Peters, E. C. (1984). A survey of the normal and pathological histology of scleractinian corals with emphasis on the effects of sedimentation stress. Ph. D. dissertation, Univ. Rhode Island

Peters, E. C., Oprandy, J. J., Yevich, P. P. (1983). Possible causal agent of 'white band disease' in Caribbean acroporid corals. I. Invertebr. Pathol. 41: 394-396

Porter, J. W. (1976). Autotrophy, heterotrophy, and resource partitioning in Caribbean reef-building corals. Am. Nat. 110: 731-742

Rogers, C. S. (1979). The effect of shading on coral reef structure and function. J. exp. mar. Biol. Ecol. 41: 269-288

Rublee, P. A., Lasker, H. R., Gottfried, M., Roman, M. R. (1980). Production and bacterial colonization of mucus from the soft coral Briareum asbestinum. Bull. mar. Sci. 30 : 888-893

Rützler, K., Santavy, D. L., Antonius, A. (1983). The black band disease of Atlantic reef corals. III. Distribution, ecology, and development. P.S.Z.N.: Mar. Ecol. 4 (4): 329-358

Scheibling, R. E., Stephenson, R. L. (1984). Mass mortality of Strongylocentrotus droebachiensis (Echinodermata: Echinoidea) off Nova Scotia, Canada. Mar. Biol. 78: 153-164

Schoenberg, D. A., Trench, R. K. (1980). Genetic variation in Symbiodinium (= Gymnodinium) microadriaticum Freudenthal, and the specificity in its symbiosis with marine invertebrates. 1. Isoenzyme and soluble protein patterns of axenic cultures of Symbiodinium microadriaticum. Proc. R. Soc. Lond. B 207: 405-427

Smith, F. G. W. (1941). Sponge disease in British Honduras, and its transmission by water currents. Ecology 22: $415-421$

Sorokin, Y I. (1973). Trophical role of bacteria in the ecosystem of the coral reef. Nature, Lond. 242: 415-417

Yevich, P. P., Barszcz, C. A. (1980). Preparation of aquatic animals for histopathological examination. In: International mussel watch. Appendix 6-13, U.S. National Academy of Sciences, Washington, D. C., p. 212-220

Yonge, C. M., Nicholls, A. G. (1931). Studies on the physiology of corals. $V$. The effect of starvation in light and in darkness on the relationship between corals and zooxanthellae. Scient Rep. Gt Barrier Reef Exped. 1928-1929 1: $177-211$ 